\title{
Lighting preferences in individual offices
}

\author{
Preferências na iluminação de salas de escritórios \\ individuais
}

\section{João Roberto Gomes de Faria Aline Yurika Inskava Sven Thomas Planitzer}

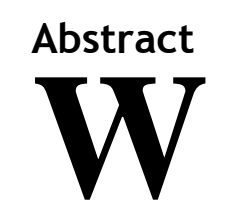

orkplaces with good daylighting offer visual comfort to users, give them a series of physiological and psychological benefits and allow good performance of visual activities, besides saving energy. However, this solution is not always adopted: lighting type preferences involve many variables besides the availability of daylight. This paper explores a case study through the analysis of questionnaire answers and computer simulations of a series of metrics related to quality of lighting with the aim of finding explanations for the lighting preferences of individual office users. The results show that, although the offices present good daylighting conditions and no glare potential, and users are satisfied with daylighting, these parameters are not sufficient to explain the predominant lighting preferences. The findings have also shown that there is no consensus about which parameters potentially cause visual comfort, while the parameters that cause discomfort are clearly identified. In addition, in this study, $49 \%$ of the preference for mixed lighting (daylight plus electrical light) can be explained by the fact that mixed lighting produces better modeling than daylighting alone.

Keywords: Daylighting. Lighting preferences. Individual office. Computer simulation.

\section{Resumo}

Ambientes de trabalho bem iluminados com a luz do dia trazem ao usuário conforto visual, uma série de benefícios físicos e psicológicos, e tornam possível o bom desempenho das atividades visuais, além de economizar energia. No entanto, nem sempre as pessoas adotam essa solução: as preferências por um tipo de

João Roberto Gomes de Faria Universidade Estadual Paulista Júlio de Mesquita Filho Bauru - SP - Brasil

Aline Yurila Inskava Universidade Estadual Paulista Júlio de Mesquita Fitho Bauru - SP - Brasil

Sven Thomas Planitzer University of Applied Sciences Zwickau

Breitenbrunn - Germany

Recebido em 07/03/16 Aceito em 20/07/16 iluminação envolvem muitas variáveis além da disponibilidade da luz. O presente trabalho explora um estudo de caso através de respostas de questionários e da simulação computacional de uma série de índices relacionados à qualidade da iluminação na busca de explicações sobre preferências de iluminação dos usuários de salas individuais de escritórios. Os resultados mostram que, embora o desempenho de aproveitamento da luz do dia das salas seja bom, não haja potencial de ofuscamento e os usuários estejam satisfeitos com a iluminação natural, esses parâmetros são insuficientes para explicar as preferências de iluminação predominantes; mostraram também que, embora não haja consenso sobre os parâmetros que potencialmente geram conforto visual, há uma clara identificação dos que geram desconforto. Além disso, no estudo em questão, 49\% dos casos da preferência predominante pela iluminação mista (natural mais elétrica) foram explicados pela melhor modelação produzida por ela em relação à produzida somente pela luz do dia.

Palavras-chaves: Iluminação natural. Preferências de iluminação. Escritório individual. Simulação computacional.

FARIA, J. R. G. de; INSKAVA, A. Y.; PLANITZER, S. T. Lighting preferences in individual offices. Ambiente Construído, 39 Porto Alegre, v. 17, n. 1, p. 39-53, jan./mar. 2017. 


\section{Introduction}

Workplaces with good daylighting allow the good performance of visual activities and provide visual comfort to users (HESCHONG, 2003). Moreover, daylight gives to people several physiological and psychological benefits, like diurnal cycle perception, circadian rhythm regulation and vitality sensation, among others (BOYCE; HUNTER; HOELETT, 2003; SMOLDERS, 2013). Finally, the use of daylighting reduces the building energy consumption (FERREIRA; SOUZA, 2009).

However, daylight is not used simply because it is available: Hopkinson, Petherbridge and Longmore (1975) discoursed half a century ago about the difficulty to prescribe the daylighting conditions to give visual comfort due to the great complexity of the intervening parameters. Furthermore, several works show a convergent result: when present in the office rooms, the blinds frequently stay fixed for a long time in positions which prevent the incidence of direct sunlight or thermal radiation only during critical periods, even after they have ceased (BOYCE et al., 2006; CORREIA DA SILVA; LEAL; ANDERSEN, 2013); so is very common rooms with closed blinds at various levels and using electric light.

In full agreement with these results, various patterns of daylight use are also seen in relation to the users of the buildings on the campus of UNESP - University of Sao Paulo State in Bauru (SP). The buildings of the Department of Architecture, Urbanism and Landscape (DAUP) and the Department of Design (DESIGN), both in the School of Architecture, Arts and Communication, were designed to take advantage of the daylight according with the activities of teachers in their offices and provide thermal comfort to users, avoiding direct solar irradiation in the inner rooms; however, the external view of the facades does not show anything different than the other campus buildings, with lowered blinds and use of electric lighting.

Thus, this study aims to test if the teachers' preferences for lighting at the DAUP and DESIGN buildings' office rooms could be explained by survey with questionnaires and lighting metrics. The main procedure is to compare data obtained from questionnaires in which teachers responded to questions about items that potentially influence the choice of forms of lighting and their preferences about it, with metrics of lighting obtained by computational simulation. These metrics are mostly daylighting because the work time in these buildings is predominantly daytime.

\section{Background}

Personalization of workspaces is one way to make it familiar and comfortable and to define the user's identity (BRUNIA; HARTJES-GOSSELINK, 2009). According Veitch (2001) the lighting control, when possible (like in individual office rooms) is part of this personalization: it is used to increase the interest and, consequently, the appreciation (extracted meanings of observed scenes) and the affection (emotional response to that meanings) by the space, with the heterogeneous luminance distributions; however, there is no consensus respect to the luminance amount and heterogeneity degree. The author emphasizes also the necessity of better understanding the factors related to the appreciation and affection to better predict the impact of light on people, as well for defining the prediction tools. The complexity of this issue continues to be approached in other works: they show that the preference for certain lighting conditions involves a great number of variables besides the photometric ones (basically illuminance and luminance and their derivatives), as mood and fatigue (VEITCH, 2001), the exterior view provided by openings (TUAYCHAROEN; TREGENZA, 2005), cultural features (BOYCE et $a l ., 2006)$, and the variations in the individual preferences related to light quantity and distribution that provides visual comfort to users (HESCHONG, 2012).

In another approach, the use of metrics of lighting performance in workspaces should also provide visual comfort, while they reduce the possibility of discomfort factors (HESCHONG, 2012). They are present in the directives of NBN EN 12464-1:2011 (EUROPEAN..., 2011) and NBR ISO/CIE 89951:2013 (ABNT, 2013), related to the compliance with minimum illuminance on the work plan and to avoid glare.

One of the first metrics for daylight performance evaluations in buildings is the Daylight Factor (DF), a ratio of illuminance on the given plan at a indoor point to the simultaneous exterior illuminance on a horizontal plane under an unobstructed CIE (Commission Internationale de l'Eclairage) overcast sky (IES..., 2012). Since the sunlight is excluded from that CIE sky, DF is a static daylight metric and its values are orientation independent (REINHART; MARDALJEVIC; ROGERS, 2006), which limits its application in post occupational evaluations. Due to the great variability of sky conditions in real situations, recent works use climate-based daylighting 
modeling (CBDM) (BOYCE, 2014) to calculate dynamic daylight metrics as Daylight Autonomy (Daylight Autonomy, DA) the Useful Daylight illuminance (UDI), and others. DA is the percentage of working hours when a minimum work plane illuminance (usually that recommended by the NBR ISO/CIE 8995-1:2013 (ABNT, 2013)) is maintained by daylight alone (REINHART, 2001) and UDI divides the working hours into three bins: with insufficient daylight (below 100 lux), with useful daylight (from 100 to 2000 lux) and with too much daylight (above 2000 lux) (NABIL; MARDALJEVIC, 2005). From these concepts and supported by field work (HESCHONG, 2012) IES (Illuminating Engineering Society) derived two metrics from qualifying rooms with respect to the daylight performance: Spatial Daylight Availability (sDA) and the Annual Sunlight Exposure (ASE), present in the LM-83-12 (IES..., 2012): sDA is the DA attended in a minimum area of the room in a fraction of work time (e.g. 300 lux in 50\% work time: $\mathrm{sDA}_{300 / 50 \%}$ ) and the ASE is the percent of an analysis area that exceeds a specified direct sunlight illuminance level in a fraction of the annual work time (e.g. 1000 lux in 250 hours per year: $\left.\mathrm{ASE}_{1000,250 \mathrm{~h}}\right)$. The compliance with the minimum values of sDA is similar to the requisites of the standards' minimal illuminances on workplaces in the dynamic and spatial context of the daylight, while the compliance with the ASE avoids the glare due to the direct sunlight.

The distributions of luminances from surfaces and light sources to the eye and of vertical illuminances at the eye height are used to evaluate the visual comfort since they are related to the possibility of glare. There are several glare indexes, but the Daylight Glare Probability (DGP) (WIENOLD; CHRISTOFFERSEN, 2006) is the most robust for glare analysis under daylight, according to Jakubiec and Reinhart (2012). Moreover, while other indexes consider the subject in a static position, these authors proposed also an "adaptive zone", a lateral range of 45 degrees each side of the visual axis to approximate the visual field due to small head movement in DGP calculations. They also propose limit values of DGP according to effects of glare on people: glare is imperceptible if $\mathrm{DGP} \leq 0.35$, perceptible if $0.35<\mathrm{DGP} \leq 0.40$, and disturbing if DGP >0.40). These limits are instantaneous and do not consider effects of attenuation or intensification of glare due to exposure time to brightness source. Vásques et al. (2015) present a preliminary study to weigh the glare index with the rate of looking to the brightness source; unfortunately, the proposal needs to be better detailed for using in annual calculations.

Finally, some works state that the visual comfort is related to aesthetic qualities, more specifically the modeling by the light of objects and textures, and propose indexes with preferred ranges by users. The metrics used are again illuminance dependents. The first one is the relation between the vector (direct light) illuminance and scalar (diffuse light) illuminance $\left(\mathrm{E}_{\mathrm{v}} / \mathrm{E}_{\mathrm{s}}\right)$, which is analyzed together with the vertical angle of incidence of $E_{v}(\alpha)$ (CUTTLE, 2008). Another one is the relation between the cylindrical illuminance (which focuses horizontally on the face of a cylinder) and the horizontal illuminance (which falls on a horizontal plan) $\left(\mathrm{E}_{\mathrm{cyl}} / \mathrm{E}_{\mathrm{h}}\right)$ from NBN EN 12464-1:2011 (EUROPEAN..., 2011).

In summary, at least three kinds of luminous metrics can condition the visual comfort in office rooms, together with subjective reasons, and how people handling the lighting controls, if possible, to get the best visual conditions for themselves. This work evaluates which subjective factors are predominant and which of those luminous metrics best explain the results of that handling.

\section{Materials and method}

The method used in this study was the intercomparison of answers to questionnaires administered to users of the DESIGN and DAUP buildings office rooms and of these analyses with data resulting from computer simulations of natural and electric lighting performance metrics related to the use of daylight in the room and visual comfort.

Partially cloudy skies are predominant in Bauru (lat 22 $19^{\prime} 12^{\prime \prime} \mathrm{S}$, long $49^{\circ} 03^{\prime} 36^{\prime \prime} \mathrm{W}$ ), where the study was carried out. In the drier and colder season (mid-year) the sky is cleaner while in rainy and hotter season (near the end of the year it is more cloudy; in other periods the cloud cover is variable, subject to the movement of hot or cold air masses. The main local climatic characteristic is the relatively high daily thermal amplitude (13 to 15 degrees Celsius) along the entire year; in the afternoon the temperatures frequently exceed 30 degrees Celsius and the mornings are cool or cold. So, rarely the buildings occupants use the solar radiation to heat; on the contrary, they avoid the solar exposure in their workplaces the entire year. Moreover, the buildings were designed to avoid direct sunlight, by combining their orientation with shading devices in their windows. 


\section{Questionnaires and subjects}

A questionnaire translated from Hygge and Löfberg (1997) with structured multiple choice answers was used to determine the parameters that potentially interfere with the room lighting. These parameters are related to the user (among which age, gender, right- or left-handed, use of glasses, sensitivity to excess and lack of light) and to the room (floor, orientation, number of occupants, position and orientation of the user in the room and condition of the blinds - open, partially closed or closed). It has also collected, by means of semantic scales, the level of satisfaction of users in relation to environmental variables (lighting, noise, odor, and temperature) and physical/psycho-physical (window size, visual from the workstation, and privacy). The questionnaires were not identified to ensure privacy to the respondents; so, the answers show the building, the floor and the facade of the respondent's room, but not exactly his room.

Later a second questionnaire (available online annex to this paper at the Ambiente Construído website) was prepared, also with closed multiple choice questions, to detail some points of the first survey, as daylight sufficiency, shade, and directionality; brightness perceived by the window; appearance of the room ceiling with open blinds and off lamps; time of computer's daily use; and preferred angle of louver blades. In this questionnaire the question to the statement of preference for type of lighting (natural/electric/mixed) by compositions of blinds positions and use or not of the electric light was changed, since during the day does not occur lighting exclusively by electrical lamps: the illumination is mixed even with closed blinds, because they allow the entry of a quantity, even small, of daylight. In addition, some questions were designed to check the consistency of the answers about a particular topic. The privacy policy of the first questionnaire was maintained.

The first questionnaire was distributed to the subjects to fill and subsequent return and the second was applied by the researcher. In both cases, the subject remained anonymous. Alongside the application of the second survey, the positions of the blinds were collected and, when they were total or partially closed, also the tilt angles of their blades, as the reference for the simulations. The analysis of the responses was made by crossing conditioning parameters of the room lighting with the other collected data.

The universe of subjects to applying the questionnaires was composed of all the teachers of the two buildings (21 in DAUP and 16 in DESIGN). Twenty-seven subjects answered the first questionnaire (14 in DAUP and 13 in DESIGN, according to Table 1), with predominant age 40-59 years, while 23 subjects composed the second sample (12 in DAUP and 11 in DESIGN, according to Table 2) in the same previous age group.

Table 1 - Features of the first sample

\begin{tabular}{l|l|c|c|c}
\hline \multirow{2}{*}{ Feature } & \multirow{2}{*}{ Class } & \multicolumn{2}{c|}{ Building } & \multirow{2}{*}{ Total } \\
\cline { 3 - 4 } & & DAUP & DESIGN & \\
\hline \multirow{2}{*}{ Gender } & male & 6 & 7 & 13 \\
& female & 7 & 3 & 13 \\
& not declared & 0 & 1 & 1 \\
\hline \multirow{2}{*}{ Room occupancy } & individual & 9 & 7 & 16 \\
& double & 5 & 6 & 11 \\
\hline \multirow{2}{*}{ Room's floor } & ground & 8 & 5 & 13 \\
& upper & 6 & 8 & 14 \\
\hline \multirow{2}{*}{ Room's facade } & front & 6 & 7 & 13 \\
& rear & 8 & 6 & 14 \\
\hline
\end{tabular}

Table 2 - Features of the second sample

\begin{tabular}{l|l|c|c|c}
\hline \multirow{2}{*}{ Feature } & \multirow{2}{*}{ Class } & \multicolumn{2}{c|}{ Building } & \multirow{2}{*}{ Total } \\
\cline { 3 - 4 } & & DAUP & DESIGN & \\
\hline \multirow{2}{*}{ Gender } & male & 5 & 6 & 11 \\
& female & 7 & 5 & 12 \\
\hline \multirow{2}{*}{ Room occupancy } & individual & 10 & 4 & 14 \\
& double & 2 & 7 & 9 \\
\hline \multirow{2}{*}{ Room's floor } & ground & 2 & 5 & 7 \\
& upper & 7 & 7 & 16 \\
\hline \multirow{2}{*}{ Room's facade } & front & 6 & 5 & 11 \\
& rear & 6 & 6 & 12 \\
\hline
\end{tabular}

42 Faria, J. R. G. de; Inskava, A. Y.; Planitzer, S. T. 


\section{Computational modeling and indexes calculation}

Due to the enormous amount of calculations required to run dynamic daylight simulations (DDS), computer programs which output sensor grid illuminance and sun penetration with hourly results are necessary. IES Daylight Metrics Committee (2012) mentions the Radiance Lighting Simulation System (or simply Radiance) (WARD, 1994), and Daysim (REINHART, 2001), based on its algorithms, is also used in the recent literature. Both programs have been validated by several studies (GRYNBERG, 1989; MARDALJEVIC, 1999; REINHART; WALKENHORST, 2001); thus both are indicated for use in the present work. Simulations of daylight were performed with the Daysim, and the Radiance was used to generate electric lighting data.

Two types of metrics were used: one related to room performance as the daylight use and another to the user's visual comfort.

In the first category, the two metrics of spatial daylight distribution from LM-83-12 were simulated: Spatial Daylight Availability (sDA) and Annual Sunlight Exposure (ASE).

In turn, a set of two metrics related to visual comfort was also simulated: the estimation of glare and the modeling produced by the light (the latter applied not only to daylight). The selected glare index was the Daylight Glare Probability (DGP) because it is specific for natural lighting. Both of the most popular indicators of modeling were chosen: the relation between the vector and scalar illuminance versus the incidence of the vector illuminance height $\left(E_{v} / E_{s}\right.$ versus $\left.\alpha\right)$ and the relation between the cylindrical and horizontal illuminance $\left(\mathrm{E}_{\text {cyl }} / \mathrm{E}_{\mathrm{h}}\right)$ from the NBN EN 12464 1:2011 (EUROPEAN..., 2011). These two indexes are computed at the users' head height.

The simulations were performed in models elaborated from the teachers' office rooms of DESIGN and DAUP buildings. The rooms of both buildings have identical geometry and are occupied by one or two people (in this case, one of them stay only one or two days by week in the room; thus these office rooms have an individual occupation in the most of the time). All the office rooms have two tilting windows with common glass: at the facade, and at the rear wall, above the door. The facade window has manually operated horizontal blinds with blades brushed aluminum and 2.5 centimeters wide (Figure 1). The rooms are equipped with four luminaries, each with two fluorescent tubes of $32 \mathrm{~W}$ with the color temperature of $4000 \mathrm{~K}$ and $\mathrm{RCI}=60$.

Rooms in two positions were studied: one on the upper floor at the front facade of DESIGN building (azimuth -7 degrees, named NNE in this study), which corresponds to the greater exposure to the sky and direct sunlight, and the second on the ground floor at the rear facade of DAUP building (azimuth 173 degrees, named SSO), which corresponds to the lower exposure to those variables (Figure 2). By extension, other rooms have intermediate levels of daylight exposition among the two studied.

Each room was modeled with a set of layouts. Due to the use of standard furniture, there are basically two arrangements in rooms with small variations in positions, which are confirmed by the users' answers to the first questionnaire about the orientation of the predominant views while working. They are mirrored in the rooms due to positions of the doors at left or right (Figure 3). Although it is possible, in fact there are no layouts with desks in front of the facade window with users looking directly to it: the high ranges of luminance between the workplace (mainly computer video displays) and the exterior could cause excessive glare. Figure 4 illustrates the views from the users' positions to the windows: mainly on the NNE facade the windows are very bright and users avoid sitting facing them; so, only people sitting in the positions at the rear in layouts for two people have one of the views directly to them.

Figure 1 - The standard room with main dimensions and superimposed luminaries (in red)

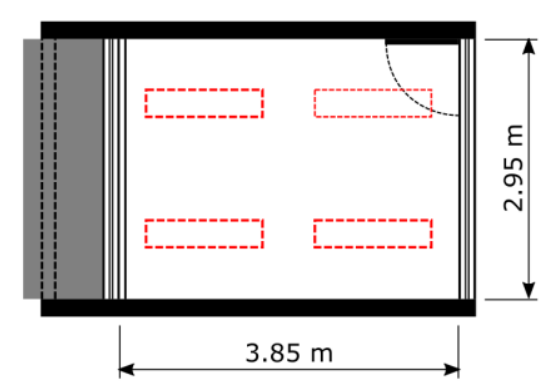

(a) Plan view

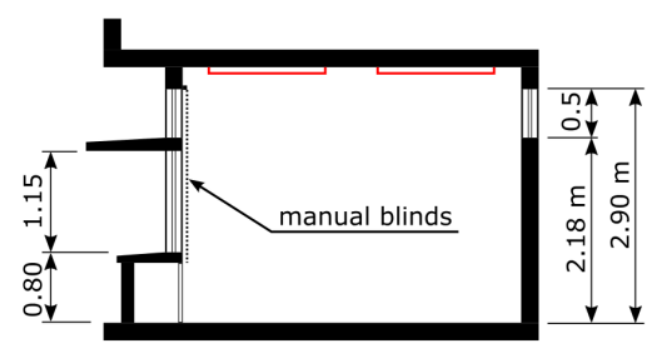

(b) Longitudinal section 
Figure 2 - (a) Front facade (NNE) of the DESIGN building, highlighting the position of the room to be modeling; in the background is the front facade of the DAUP; e (b) rear facade (SSO) of the DAUP building, highlighting the position of the room to be modeling - users of the two ground floor rooms located behind the electric power cabin did not respond to the questionnaires, since they are out of the general pattern, with a large obstruction facing the windows
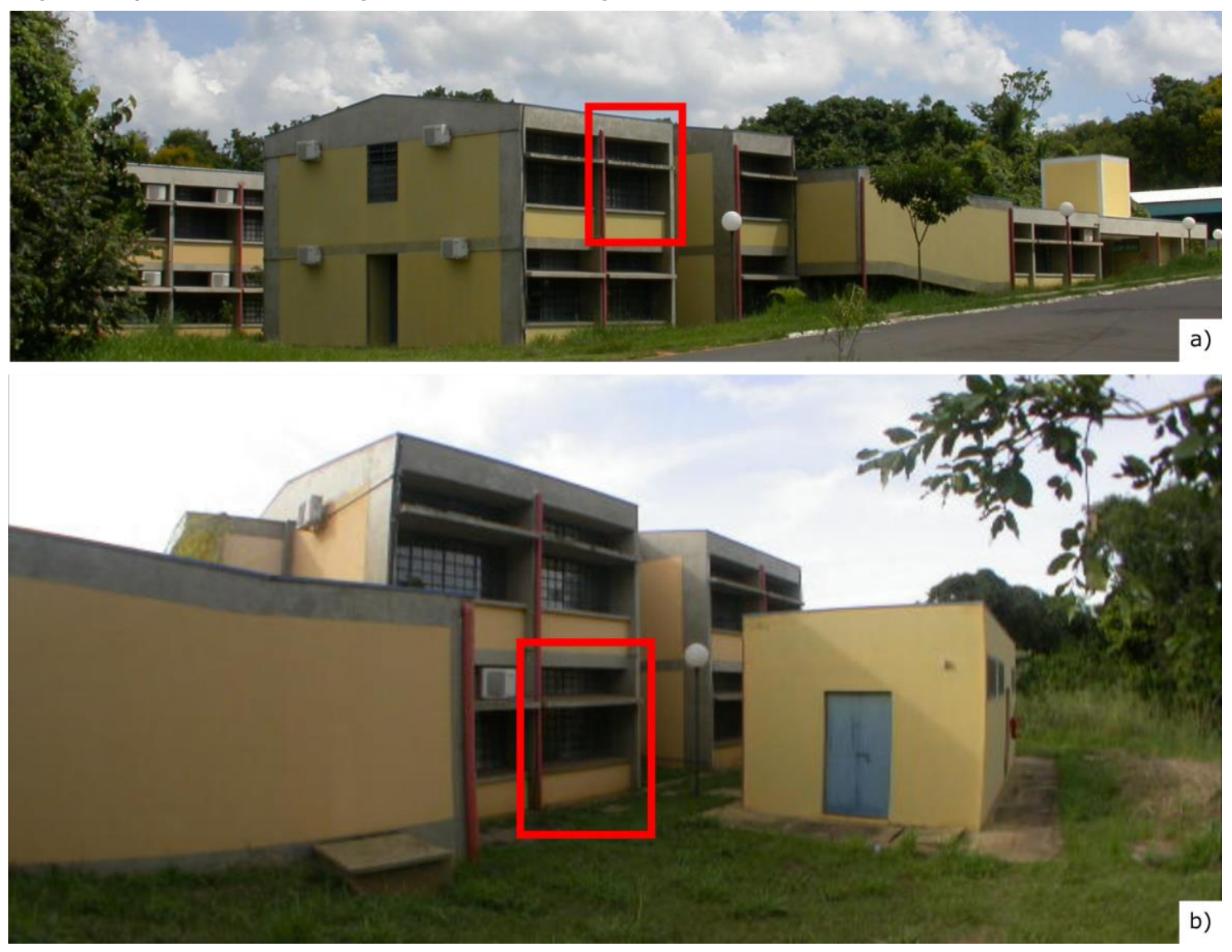

Figure 3 - Modeled layouts of the office rooms with the positions of the users $(\bullet)(F-f r o n t, M$ - middle, $B$ - back) and respective typical directions of views ( $L$ - left, $R$ - right, $F$ - front, $B$ - back)

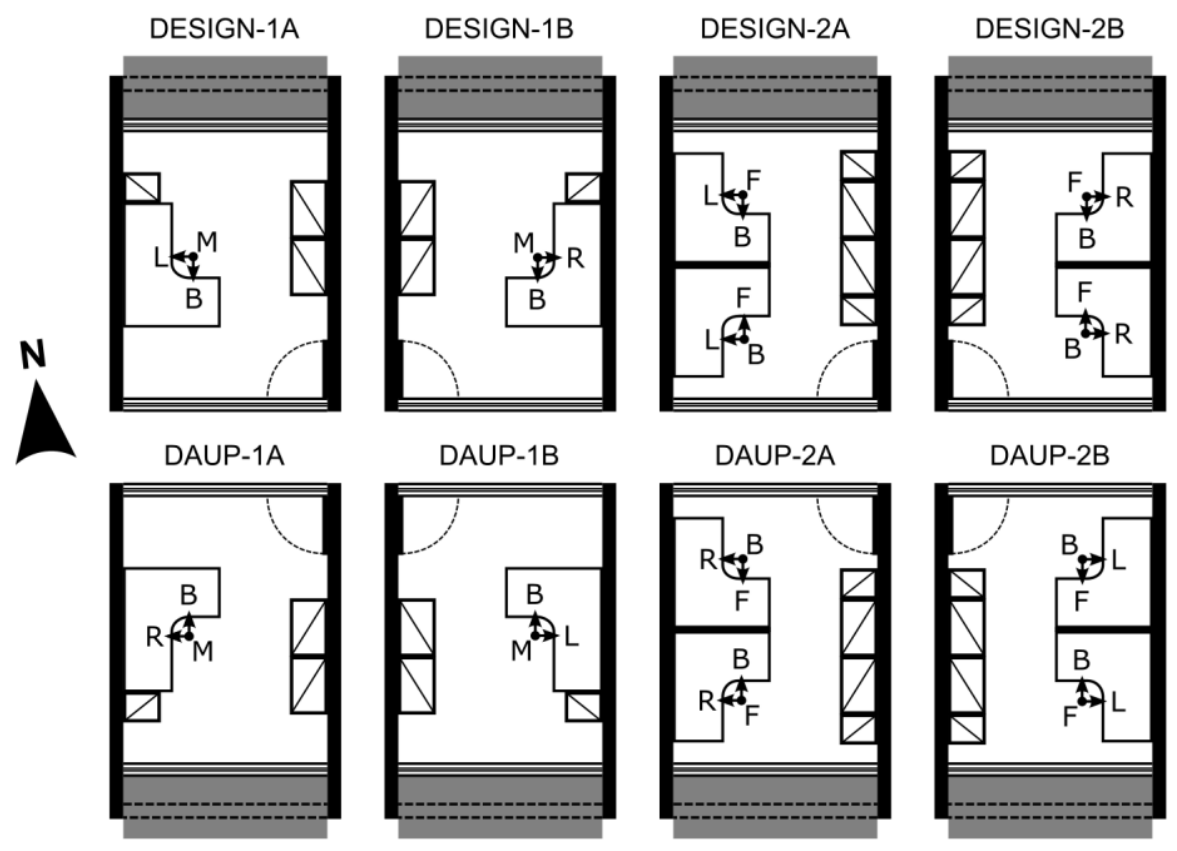

44 Faria, J. R. G. de; Inskava, A. Y.; Planitzer, S. T. 
Figure 4 shows too that the windows are brighter at the NNE facade, despite the overcast sky used to compose the images. The reason for this is a dense grove about 8 meters from the DAUP's SSO facade with 7 meters high on average.

The modeling of the rooms, as well as the configuration of Daysim, was done according to the guidelines of the IES LM-83-12. In each simulation were considered:

(a) typical layouts for one and two occupants and their symmetric (4 layouts by room, according to Figure 3);

(b) a horizontal mesh at 2.54 centimeters above the plane of the tables ( 0.75 meters $)$ of $4 \times 6$ cells with $0.60 \times 0.55$ square meters and lateral offset of 0.275 meters; the horizontal illuminance sensors were arranged in centers of these cells (Figure 5);

(c) sensors at 1.2 meters height from the floor (a seated person) to DGP calculation in "adaptive zone" (45 degrees each side from the axis view) in two orientations for each user (looking at the two
"L" braces of the desk, as in Figure 5, also according the users' answers about predominant views); thus, each user covers a horizontal field of view of 180 degrees (90 degrees each perpendicular direction);

(d) six sensors at 1.2 meters height from the floor for each user (directed to up, down, front, back, left, and right, respectively), to calculate the modeling variables;

(e) Daysym's Dynamic Shading Module configured in advanced mode (dynamic shading mode) with manually operated blinds in three possible positions: completely open, lowered with horizontal blades ( 0 degrees) and lowered with the blades tilted at 45 degrees (Figure 6). These situations were the most frequently found in the survey carried out in parallel with the implementation of the second questionnaire; and

(f) the simulations were performed with the TMY file with data of Bauru weather available on the website of LabEEE (UNIVERSIDADE..., 2012).

Figure 4 - Fisheye views from users' positions to facade window under a CIE standard overcast sky for the set of studied layouts rendered with Radiance - the mask shows the peripheral vision limits (in red) and the panoramic view limits (in blue) - luminaries are not represented

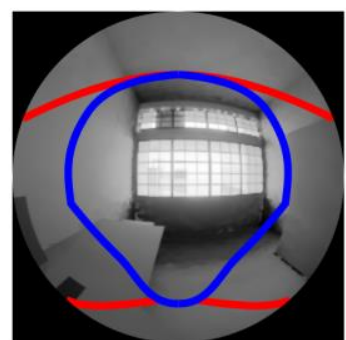

DAUP-1A Middle

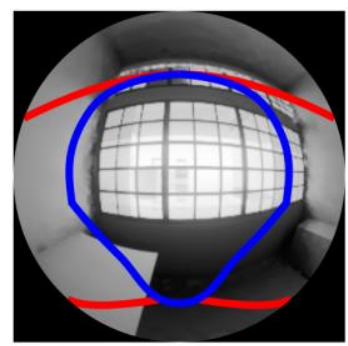

DAUP-2A Front

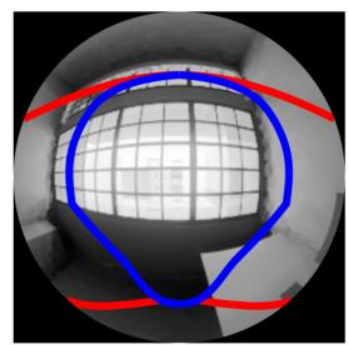

DAUP-2B Front

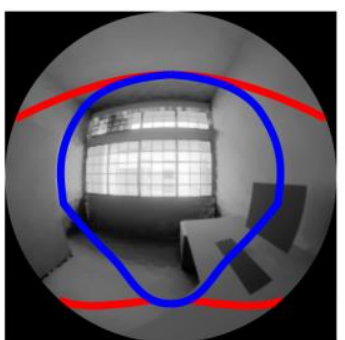

DAUP-1B Middle

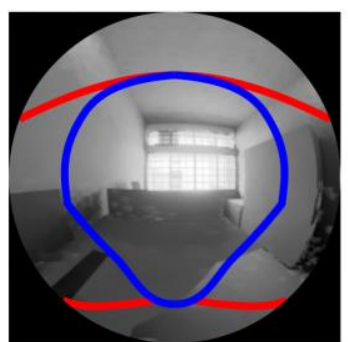

DAUP-2A Back

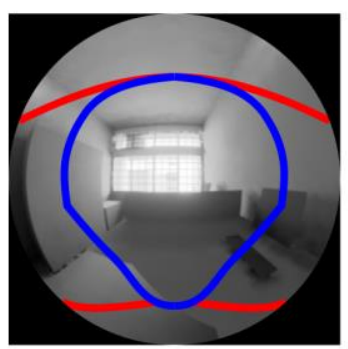

DAUP-2B Back

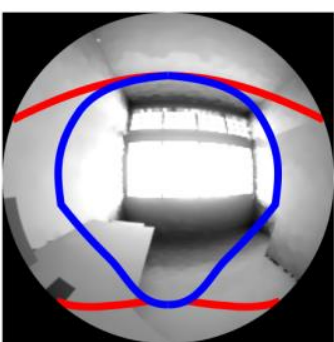

DESIGN-1A Middle

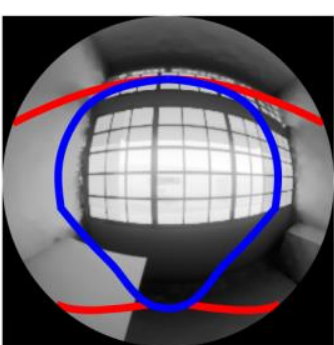

DESIGN-2A Front

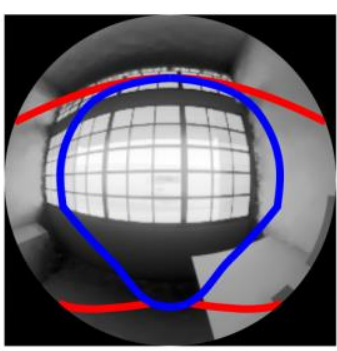

DESIGN-2B Front

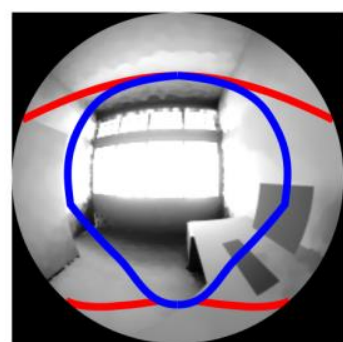

DESIGN-1B Middle

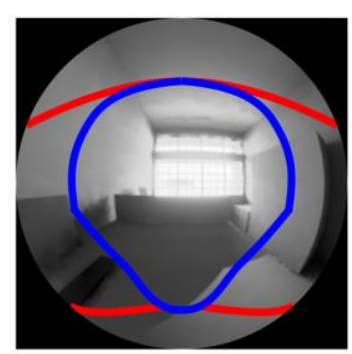

DESIGN-2A Back

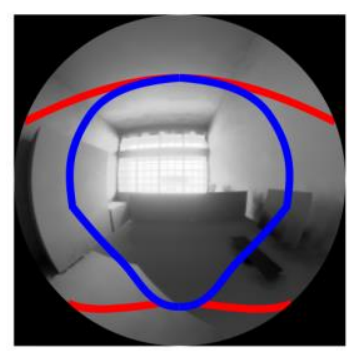

DESIGN-2B Back

Source: mask adapted from Boyce (2003). 
Figure 5 - Central points of the mesh for computational simulation of the horizontal illuminance $(\bullet)$ and the users' positions, in which the modeling variables were simulated with respective views for calculation of DGP $(\bullet)$

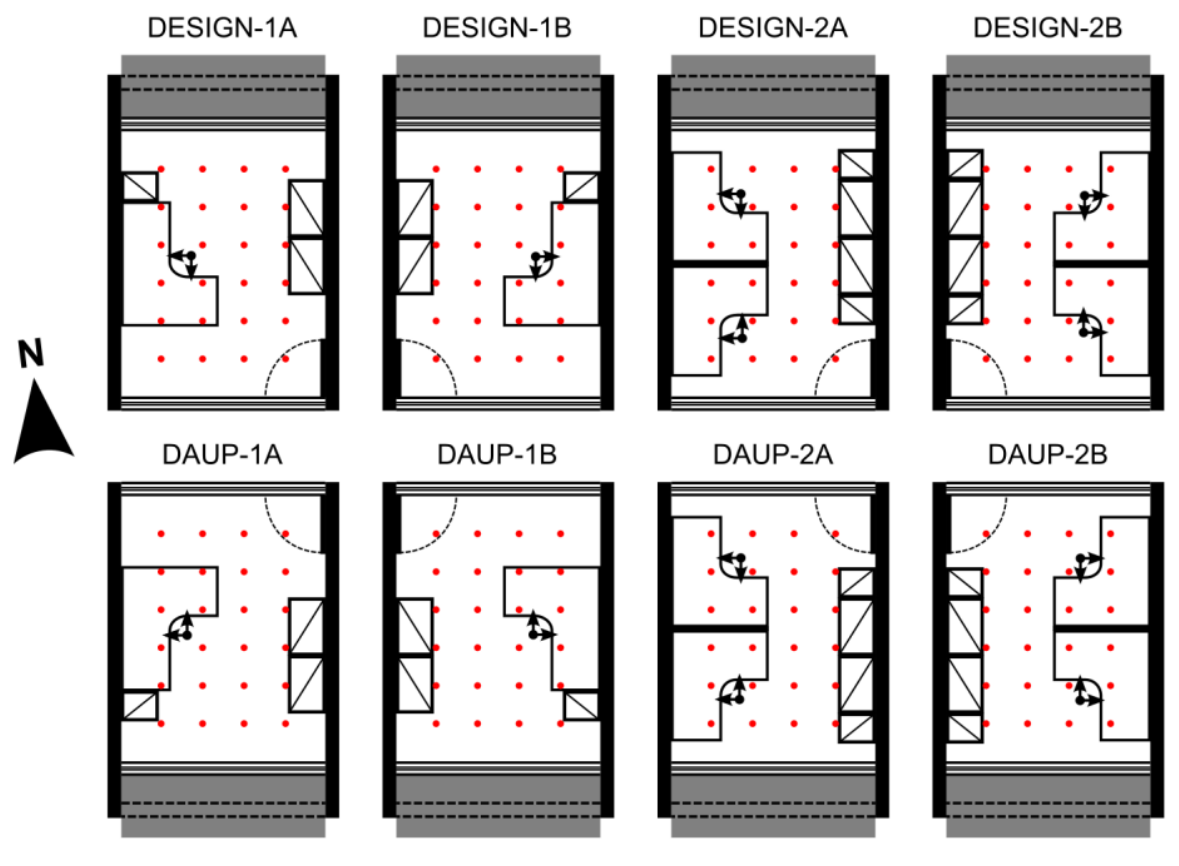

Figure 6 - Sections of lowered blinds with blades tilted at: a) 0 degrees (horizontal); b) 45 degrees

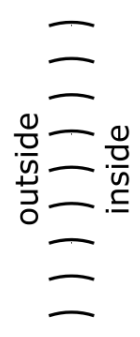

a)

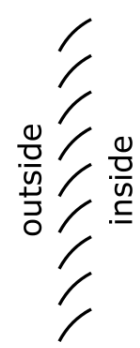

b)
The reflectance of surfaces, including the grass and the plane formed by the dense grove back DAUP, was determined by the procedure set out by Cuttle (2008) with a sheet of paper as the reference (according to DORNELLES, 2008) and its roughness was estimated by the similarity of the Radiance's database materials. The blind reflectance was obtained with the Radiance Colour Picker (JACOB, 2016).

The results of Daysim simulations were treated numerically to generate SAD, ASE and DGP values. The results of simulations of electric lighting from Radiance were coupled to the Daysim's to calculate the values of $\mathrm{E}_{\mathrm{v}} / \mathrm{E}_{\mathrm{s}}, \mathrm{E}_{\mathrm{cyl}} / \mathrm{E}_{\mathrm{h}}$ and $\alpha$. The values of SAD and ASE were calculated according to the procedures established in the IES LM-83-12 and the indicators of modeling according to the procedures set out by Cuttle (2008) and Duff (2012).

\section{Results}

\section{Questionnaires}

Most of the subjects (13 DAUP and 12 DESIGN) are satisfied with the room lighting when answering the first questionnaire; only two persons (one each building) are unsatisfied with the heterogeneous distribution of light in their workplace. On DAUP 7 subjects use exclusively daylight, 2 use electrical lighting and 5 use mixed lighting. On DESIGN, 4 teachers use daylight and 13 use mixed lighting. The external view was considered predominantly satisfactory (8 DAUP and 7 DESIGN), pleasant (11 DAUP and 6 DESIGN) and bright (6 DAUP and 7 DESIGN).

46 Faria, J. R. G. de; Inskava, A. Y.; Planitzer, S. T. 
No relation was found among the lighting preferences and satisfaction with outside view with the answers to other questions.

Table 3 shows the main advantages (from 10 options) and disadvantages (from 9 options) pointed by the subjects concerning windows. Notice that the advantage related to daylight, while listed among the main ones, is not the most important; furthermore, aesthetic attributes (view, space and monotony break) are among the main advantages. However, disadvantages related to poor daylight quality among the first, showing that in office work, the visual discomfort is soon perceived when there is potential for it.

Correspondences were found among some responses in Table 3 and the subject position in the building:

(a) outside view - mostly upper floor: unbalanced view (greater fraction of sky);

(b) fresh air - predominantly in the DAUP ground floor and DESIGN upper floor; without plausible interpretation;

(c) daylight - most frequently the ground floor in DAUP and upper floor in DESIGN: no likely explanation; (d) monotony break or "it makes the room look larger" - absolute predominance of DAUP: factors related to the perception of space, one of the themes studied by the building teachers;

(e) too much sunlight or glare - NNE facades: longest period with close exposure to the solar path; and

(f) reducing privacy - DAUP's rooms NNE and DESIGN's SSO facades: the rooms facing the neighboring building; however, the same subjects identified the view from the window as agreeable.

With the reshaping of the indication of the preferred parameters lighting in the second questionnaire, the results in Table 4 show that exclusively natural lighting (off electric lights) is used by less than half of the subjects in total (7 in DAUP and 2 in DESIGN). The rest keeps the electric lighting with fully or partially closed blinds. So, the view of the exterior, appointed in the previous questionnaire as an advantage by the majority, and also for the literature as desirable, is not fully exploited.

Again there is no relation between the responses of Table 4 and others collected with the questionnaire.

Table 3 - Main advantages and disadvantages of windows identified by the subjects - the values correspond to the sum of the weights assigned to the alternatives by the subjects $(3$ = most important; $0=$ no importance)

\begin{tabular}{l|c|c|c}
\hline & DAUP & DESIGN & TOTAL \\
\hline Advantage & \multicolumn{3}{|l}{} \\
\hline Outside view & 17 & 15 & 32 \\
\hline Fresh air & 8 & 15 & 23 \\
\hline Daylight & 12 & 10 & 22 \\
\hline It makes the room look larger & 16 & 5 & 21 \\
\hline Monotony break & 12 & 4 & 16 \\
\hline Disadvantage & \multicolumn{3}{|l}{} \\
\hline Too much sunlight & 12 & 11 & 23 \\
\hline Glare & 11 & 10 & 21 \\
\hline Reducing privacy & 10 & 9 & 19 \\
\hline Noise from outside & 8 & 10 & 18 \\
\hline Heat from outside & 8 & 9 & 17 \\
\hline
\end{tabular}

Table 4 - Preferential lighting parameters

\begin{tabular}{l|c|c|c}
\hline \multicolumn{1}{c|}{ Lighting parameters } & DAUP & DESIGN & TOTAL \\
\hline Closed blinds and electric lighting & 1 & 1 & 2 \\
Partially closed blinds and electric lighting & 4 & 6 & 10 \\
Open blinds and no electric lighting & 6 & 2 & 8 \\
Open blinds and electric lighting & 0 & 2 & 2 \\
Partially closed blinds and no electric lighting & 1 & 0 & 1 \\
\hline
\end{tabular}


Answers to some questions indicate some inconsistencies in relation to daylight quality:

(a) the amount of daylight was declared suitable by the majority ( 9 in DAUP and 5 in DESIGN); on the other hand, the predominant control of the blinds is done to reduce the brightness (6 in DAUP and 4 in DESIGN);

(b) the brightness perceived to look out the window was considered pleasant by the most (9 in DAUP and 7 in DESIGN), but the rest ( 3 in DAUP and 4 in DESIGN), concentrated on the upper floor ( 2 in DAUP and 3 in DESIGN), considered it as excessive, justifying in part the use of blinds to control it. The subjects of the upper floor, positioned mostly of 1 to 2 meters from the window (the first questionnaire responses) have an outside view made up almost exclusively of the sky, generally too bright; and

(c) most users judged the directionality of daylight as well balanced (10 in DAUP and 6 in DESIGN), confirmed by the impression that when the lighting is exclusively natural the ceiling is pleasantly bright (7 in DAUP and 6 in DESIGN); however, for almost half of the subjects ( 5 in DAUP and 5 in DESIGN) the room's ceiling is dark, indicating excessive predominance of side lighting, without reflection to up.

These contradictions seem to indicate that control of natural lighting is not done rationally, or that at least there is no clarity about what makes a pleasant lighting; however, it is clear to the subjects the reasons of their discomfort.

The daylight side entrance causes a gradient in brightness along the length of the room; however this heterogeneity was not perceived by the research subjects as a problem, unlike the directives of NBN EN 12464-1:2011 (EUROPEAN..., 2011) and NBR ISO/CIE 89951:2013 (ABNT, 2013).

In summary, the questionnaires raised some preferences for ways to control the lighting, but it was not possible to establish the causes of these preferences, confirmed by the bibliographical review previously presented in this work. This result refers to the observations of Veitch (2001) on the need for better understanding the psychological foundations of appreciation and affection, which is beyond the scope of this work.

\section{Metrics}

\section{ASE and SDA}

Values of $\mathrm{ASE}_{1000,250 \mathrm{~h}}=0 \%$ were found in the both studied rooms, that means that, there is no incidence of significant direct sunlight in work plans and, therefore, should not occur glare. On the other hand, $\mathrm{sDA}_{300,50 \%}$ varies with the orientation and location of rooms and its internal layouts; so only with the individual occupation the DESIGN office room reaches the "preferred daylight sufficiency" according to the IES LM-83-12 $\left(\mathrm{sDA}_{300,50 \%} \geq 70 \%\right)$; in all other cases the use of daylight is only "nominally acceptable" $(50 \% \leq$ $\mathrm{sDA}_{300,50 \%}<70 \%$ ) (Table 5). Notice that, to achieve those results, only in the DESIGN room (in all layouts) the Daysim considered that the blinds should be closed for $6 \%$ of the annual working hours with the blades at 0 degrees and $1 \%$ of the time with the blades at 45 degrees prevent the entry of direct sunlight (active control); Daysim kept them open for $100 \%$ of the working period in the DAUP room.

Thus, $\mathrm{sDA}_{300,50 \%}$ partially explains the preference for mixed lighting in most of the rooms, since the electric lighting is necessary to complement the daylight from approximately half of the rooms during $50 \%$ the working period of the year (considering that the performance of other rooms is intermediate among the rooms studied here). However, $\mathrm{ASE}_{1000,250 \mathrm{~h}}$ alone is insufficient to explain the preference for the closed shutters, since does not occur glare by direct incidence of sunlight into significant periods (over 250 hours in the year) and closed blinds worsen the daylighting performance. The conclusion, therefore, according to the bibliography, is that the users of this study do not have the rational behavior of shading devices operating model adopted by Daysim.

\section{DGP}

According to the value of ASE, DGP values found are all located in the range of "imperceptible glare" (Figure 7), invalidating the need to close the blinds or turn on the electric light to avoid glare. The largest DGP values occur for users of the back of DESIGN room in arrangements for two people (18\% of cases oriented NNE): the reduction of the window relative size, exposed to a large area of sky, creates contrast with the walls and the ceiling which, although with high reflectance, are shaded.

Table 5 - Spatial Daylight Availability $\left(\mathrm{sDA}_{300,50 \%}\right)$ in the studied office rooms

\begin{tabular}{|c|c|c|c|c|c|c|c|c|}
\hline Building & \multicolumn{4}{|c|}{ DESIGN } & \multicolumn{4}{|c|}{ DAUP } \\
\hline Lay out & $1 \mathrm{~A}$ & $1 \mathrm{~B}$ & $2 \mathrm{~A}$ & $2 \mathrm{~B}$ & $1 \mathrm{~A}$ & $1 \mathrm{~B}$ & $2 \mathrm{~A}$ & $2 \mathrm{~B}$ \\
\hline $\mathbf{S D A}_{300,50 \%}(\%)$ & 70 & 70 & 62 & 58 & 54 & 50 & 50 & 54 \\
\hline
\end{tabular}

48 Faria, J. R. G. de; Inskava, A. Y.; Planitzer, S. T. 
Figure 7 - Boxplots (extremes, Q1 and Q3 percentiles, median) of annual distribution of DGP in the studied rooms for different internal layouts and blinds positions (see Figure 3 for references of users' positions and views)

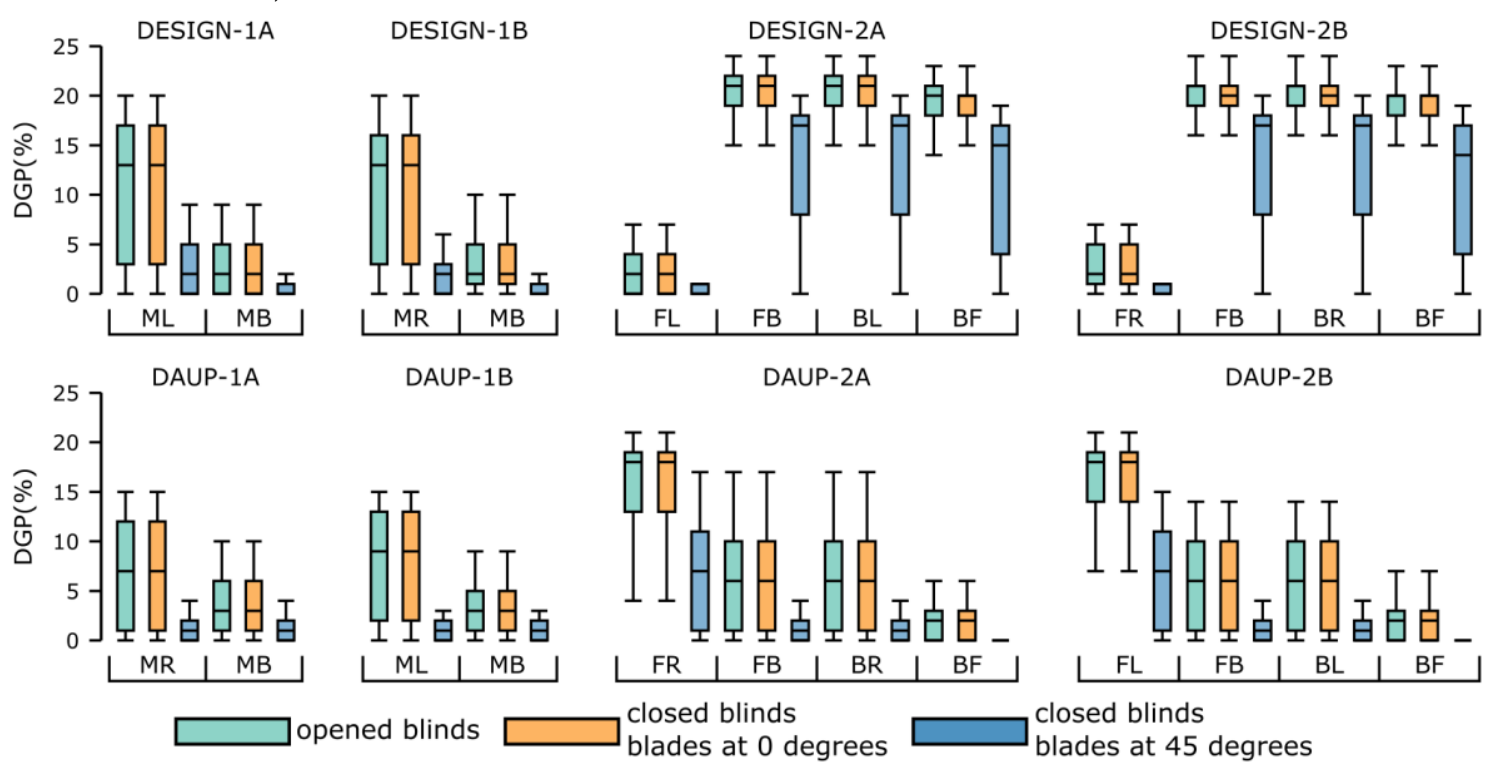

Despite these results, "too much sunlight" and "glare" were the windows' main disadvantages appointed in the second questionnaire for the two buildings' users. Future works would explore the correction of DGP values with the exposure time to the brightness source to verify if the new results correspond to the questionnaire's answers.

DGP was not calculated with lowered blinds or mixed lighting because in these two situations the absolute or relative vertical illuminance is attenuated and the glare is smaller.

\section{Modeling by the light}

The relation $E_{v} / E_{s} x \alpha$ shows a little better results, while not conclusive, on the preference of users when using mixed lighting and closing of blinds. Notice that in Figure 8, in both orientations and independently of layout, the fully open blinds produce low values of $\alpha$ (sometimes below 15 degrees) and high values of $\mathrm{E}_{\mathrm{v}} / \mathrm{E}_{\mathrm{s}}$ under daylight exclusively.

The electric lighting does not change $E_{\mathrm{v}} / \mathrm{E}_{\mathrm{s}}$ significantly when the blinds are open, but it can increase excessively the values of $\alpha$ because the fixtures have louvers, which guides the luminous flux down only: for nocturnal electric lighting, $\mathrm{E}_{\mathrm{v}} / \mathrm{E}_{\mathrm{s} \text { average }}=2.9$, standard deviation $=0.3$ and $\alpha_{\text {average }}=67.1$ degrees, standard deviation $=2.9$ degrees, both average values above the preferred range, despite the high reflectance of walls.
Lowering the blinds decreases the value of $E_{v} / E_{s}$ due to reduced brightness from outside and increases the values of $\alpha$ by reflection of daylight that focuses on the blades to the ceiling. Elevations are higher when blades stay in the horizontal position. This effect if more pronounced in rooms with individual layouts at the SSO facade, darker than the other one.

Considering only this metric, the best performances are obtained in DAUP room, especially when occupied by two people, in positions close to the window, with the blinds lowered and blades tilted 45 degrees; unfortunately, in this situation the illuminance produced by daylight is insufficient for the work. In addition, the relation $\mathrm{E}_{\mathrm{v}} / \mathrm{E}_{\mathrm{s}}$ versus $\alpha$ explains only $6 \%$ of annual work time in all the configurations (concentrated in DAUP-2A and 2B, both Front position) using daylight and blinds lowered with blades tilted 45 degrees.

The $\mathrm{E}_{\mathrm{cyl}} / \mathrm{E}_{\mathrm{h} \text { average }}$ for the nocturnal electric lighting of the rooms is 0.22 (standard deviation $=0.02$ ), below the NBN EN 12464:2011 (EUROPEAN..., 2011) recommended range. It is independent of the blinds condition. It is a low value, even with the high reflectance of the walls has the same explanation pointed previously for $\mathrm{E}_{\mathrm{v}} / \mathrm{E}_{\mathrm{s}}$ average at night. Daylight causes high ranges of $\mathrm{E}_{\text {cyl }} / \mathrm{E}_{\mathrm{h}}$, which are minimized with the horizontal illuminance produced by electric lighting (Figure 9). 
Figure 8 - Annual distribution of $E_{v} / E_{s}$ versus $\alpha$ respect to the preferred range (gray area) (see Figure 3 for references of users' positions)
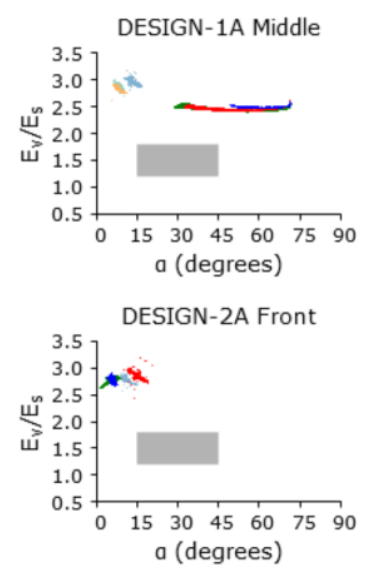

DESIGN-2A Back

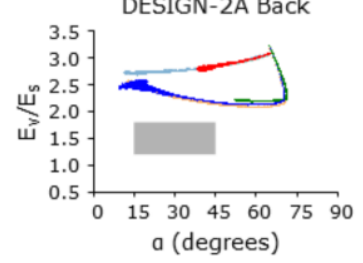

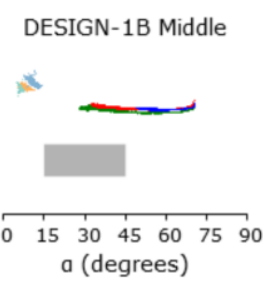

DESIGN-2B Front

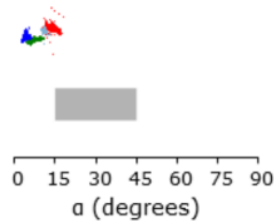

DESIGN-2B Back
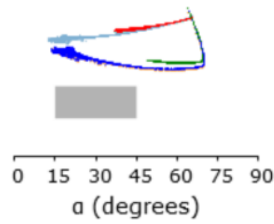

opened

Blinds

Blades

Electric lights opened

off

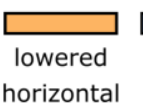

off lowered

$45^{\circ}$

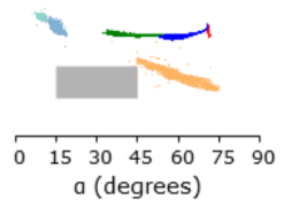

$\begin{array}{lllllll}0 & 15 & 30 & 45 & 60 & 75 & 90\end{array}$ a (degrees)

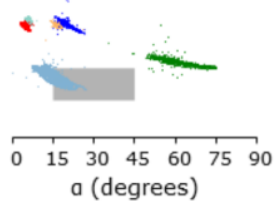

DAUP-2A Back

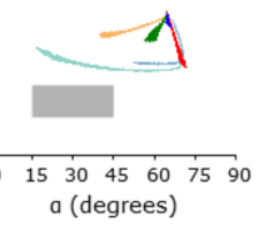

DAUP-2A Front

$\begin{array}{lllllll}0 & 15 & 30 & 45 & 60 & 75 & 90\end{array}$ a (degrees)

DAUP-2B Front

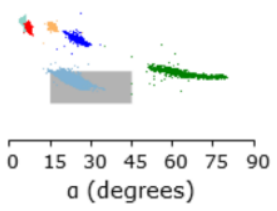

DAUP-2B Back

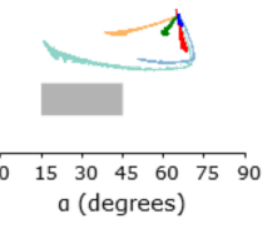

Source: preferred range: Cuttle (2008).

Figure 9 - Boxplots (extremes, Q1 and Q3 percentiles, median) of annual distribution of $E_{c y l} / E_{h}$ respect to the recommended range (gray area) (see Figure 3 for references of users' positions)

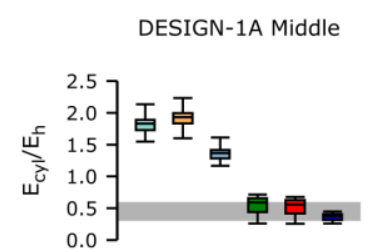

DESIGN-2A Front

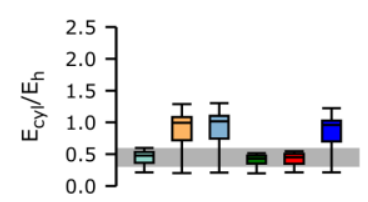

DESIGN-2A Back
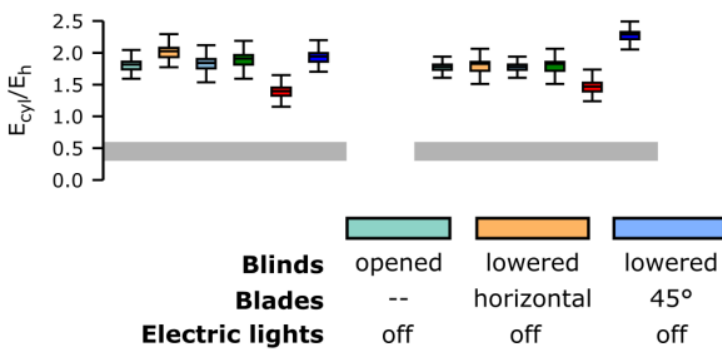

DAUP-1A Middle

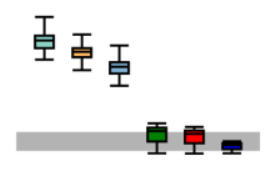

DESIGN-2B Front

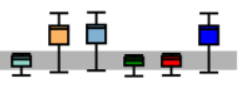

DESIGN-2B Back

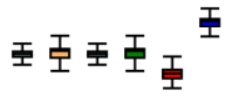

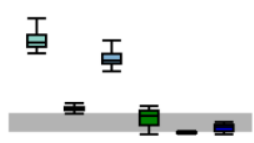

DAUP-2A Front

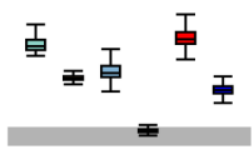

DAUP-2A Back
DAUP-1B Middle

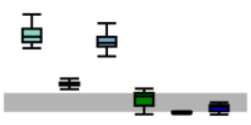

DAUP-2B Front

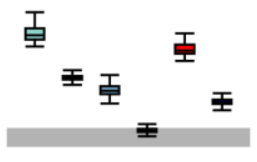

DAUP-2B Back

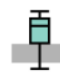

百
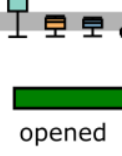

--

on lowered horizontal

on

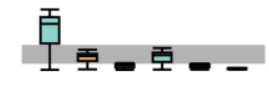

lowered

$45^{\circ}$

on

Source: recommended range: NBN EN-12464-1:2011 (EUROPEAN..., 2011). 
The lighting composed of daylight + electric light + opened blinds results in higher attendance rates in the preferred range $(49 \%$ of annual work time, equally distributed between the two orientations), followed by daylight + electric light + closed blinds with horizontal blades $(33 \%$ of annual work time: $34 \%$ in the DESIGN and $32 \%$ in DAUP). Therefore, among the variables studied, the relationship of $\mathrm{E}_{\mathrm{cyl}} / \mathrm{E}_{\mathrm{h}}$ is the one that best explains the preference of users for mixed daytime lighting and the use of blinds.

The windows' brightness and the user position have fundamental importance on these metric values: brighter windows work better (since they do not cause glare) when users are near them, and vice versa. Part of the incident daylight is reflected by the window sill and the light shelf to the ceiling, where it returns as horizontal illuminance, reducing the ratio $\mathrm{E}_{\mathrm{cyl}} / \mathrm{E}_{\mathrm{h}}$. However, when the blinds are lowered and the lamps are turn on, $E_{h}$ can excessively increase and so $\mathrm{E}_{\text {cyl }} / \mathrm{E}_{\mathrm{h}}$ can fall down under the recommended range.

\section{Conclusion}

The analysis of individual office lighting is permeated by a high degree of subjectivity in regard to the user's preferences and habits in relation to its control. This study tested two questionnaires applied to users of individual office rooms and a set of indicators of daylight room performance and visual comfort, generated by computer simulation, in a case study to explain the preference of a significant proportion of analyzed subjects by mixed lighting during the daytime work.

Questionnaire results allowed to describe the parameters involved in the illumination of buildings and establish some interrelations but do not fully explain the user's preferences. The answers to some questions make it clear the importance of connecting parameters of environmental perception phenomena; to others, to the architectural design details, for privacy maintenance. Contradictory answers to questions on the same theme also showed that the subjects did not have much clarity about the lighting quality attributes. Finally, surveys have shown that the parameters of the illumination that cause discomfort are more easily identified than those that provide comfort.

The metrics from the IES LM-83-12 (sDA and ASE) indicate good performance of the rooms in relation to the use of daylight, but assume the rational behavior of the user in control of blinds to maximize the use of natural lighting, which in fact does not occur.
DGP indicates total absence of glare, although the phenomenon has been noted in the questionnaires as one of the main reasons to close the blinds. Time factor was not considered in this work, but it may be relevant in the glare analysis: although exposure to large portions of the sky does not cause glare, it can be unpleasant for a long stay as the daytime working hours.

Metrics regards to modeling by light, especially $\mathrm{E}_{\mathrm{cyl}} / \mathrm{E}_{\mathrm{h}}$, show more consistent results of the users' preference for mixed daylighting involving daylight and electric light, eventually also with lowered blinds: in the individual offices rooms studied the lighting becomes less directional, the angle of incidence rises and exposure to large portions of sky is reduced. Summing, the room's visual aspect is pleasanter, even giving up the outside view.

Thus, the final recommendations of this work are to improve knowledge about the environmental perception of phenomena related to lighting workspaces in order to better reflect the desires of users in design parameters, and once having met the illuminance requirements, attention should be given to the modeling produced by the lighting.

\section{References}

ASSOCIAÇÃO BRASILEIRA DE NORMAS TÉCNICAS. NBR ISO/CIE 8995-1: iluminação de ambientes de trabalhos: parte 1: interior. Rio de Janeiro, 2013.

BOYCE, P. Better Metrics for Better Lighting. Newsletter - The Society of Light and Lighting, London, p. 5-7, 2014.

BOYCE, P.; HUNTER, C.; HOWLETT, O. The Benefits of Daylight Through Windows. New York: Lighting Research Center, 2003.

BOYCE, P. R. Human Factors in Lighting. $2^{\text {nd }}$ ed. London; New York: Taylor \& Francis, 2003.

BOYCE, P. R. et al. Occupant Use of Switching and Dimming Controls in Offices. Lighting

Research and Technology, v. 38, n. 4, p. 358 376, 2006.

BRUNIA, S.; HARTJES-GOSSELINK, A. Personalization in Non-Territorial Offices: a study of a human need. Journal of Corporate Real Estate, v. 11, n. 3, p. 169-182, 2009.

CORREIA DA SILVA, P.; LEAL, V.; ANDERSEN, M. Occupants Interaction With Electric Lighting and Shading Systems in Real Single-Occupied Offices: results from a monitoring campaign. Building and Environment, v. 64, p. 152-168, 2013. 
CUTTLE, C. Lighting by Design. $2^{\text {nd }}$ ed. Oxford, UK: Butterworth-Heinemann, 2008.

DORNELLES, K. A. Absortância Solar de Superfícies Opacas: métodos de determinação e base de dados para tintas látex acrílica e PVA. Campinas, 2008. Thesis (Doctorate degree in Civil Engineering) - Universidade Estadual de Campinas, Campinas, 2008.

DUFF, J. The 2012 SLL Code for Lighting: the impact on design and commissioning. Journal of Sustainable Engineering Design, v. 1, n. 2, 2012.

\section{EUROPEAN COMMITTEE FOR}

STANDARDIZATION. NBN EN 12464-1: light and lighting: lighting of work places: part 1: indoor work places. Brussels, 2011.

FERREIRA, C. C.; SOUZA, R. V. Investigação Sobre o Potencial de Economia de Energia da Iluminação Natural. In: ENCONTRO

NACIONAL, 10; ENCONTRO LATINO AMERICANO DE CONFORTO NO AMBIENTE CONSTRUÍDO, 6., Natal, 2009. Anais... Natal: ANTAC/UFRN, 2009.

GRYNBERG, A. Validation of RADIANCE. Berkeley: Lawrence Berkeley Laboratory, 1989.

HESCHONG, L. Windows and Offices: a study of office worker performance and the indoor environment. Technical Report, Fair Oaks, California: California Energy Commission, 2003.

HESCHONG, L. Daylight Metrics. Sacramento: California Energy Commission, 2012. Final Project Report.

HOPKINSON, R. G.; PETHERBRIDGE, P.; LONGMORE, J. Iluminação Natural. 2. ed. Lisboa: Fundação Calouste Gulbenkian, 1975.

HYGGE, S.; LÖFBERG, H. A. User Evaluation of Visual Comfort in Some Buildings of the Daylight Europe Project. In: RIGHT LIGHT, 4., Stockholm, 1997. Anais... . p. 69-74. Stockholm: European Council for an Energy Efficient Economy, 1997.

IES DAYLIGHT METRICS COMMITTEE. Approved Method: IES Spatial Daylight Autonomy (sDA) and Annual Sunlight Exposure (ASE). New York: Illuminating Engineering Society of North America, 2012.

JACOB, A. Colour Picker. Colour Picker for Radiance. Available at: <http://www.jaloxa.eu/resources/radiance/colour_ picker/index.shtml>. Access in: May 24, 2016.

JAKUBIEC, J. A.; REINHART, C. F. The "Adaptive Zone": a concept for assessing discomfort glare throughout daylit spaces. Lighting Research and Technology, v. 44, n. 2, p. 149-170, 2012.
MARDALJEVIC, J. Daylight Simulation: validation, sky models and daylight coefficients. Leicester, 1999. Thesis (Doctorate degree) - De Montfort University, Leicester, 1999.

NABIL, A.; MARDALJEVIC, J. Useful Daylight Illuminance: a new paradigm for assessing daylight in buildings. Lighting Research and Technology, v. 37, n. 1, p. 41-57, 2005.

REINHART, C. F. Daylight Availability and Manual Lighting Control in Office Buildings: simulation studies and analysis of measurements. Karlsruhe, 2001. Thesis (Doctorate degree in Architecture) - Faculty of Architecture, Technical University of Karlsruhe, Karlsruhe, 2001.

REINHART, C. F.; MARDALJEVIC, J.; ROGERS, Z. Dynamic Daylight Performance Metrics for Sustainable Building Design. Leukos, v. 3, n. 1, p. 7-31, 2006.

REINHART, C. F.; WALKENHORST, O. Validation of Dynamic RADIANCE-Based Daylight Simulations for a Test Office With External Blinds. Energy and Buildings, v. 33, n. 7, p. 683-697, 2001.

SMOLDERS, K. C. H. J. Daytime Light Exposure: effects and preferences. Eindhoven, 2013. Thesis (Doctorate degree) - Technische Universiteit Eindhoven, Eindhoven, 2013.

TUAYCHAROEN, N.; TREGENZA, P. R. Discomfort Glare From Interesting Images. Lighting Research and Technology, v. 37, n. 4, p. 329-338, 2005.

UNIVERSIDADE FEDERAL DE SANTA CATARINA. LABORATÓRIO DE EFICIÊNCIA ENERGÉTICA EM EDIFICAÇÕES. Arquivos climáticos INMET 2012. Available at: http://www.labeee.ufsc.br/sites/default/files/arquiv os_climaticos/arquivos/SP_Bauru.epw. Access in: April 12, 2014.

VÁSQUEZ, N. G. et al. Metodologia Experimental Para Caracterização do Campo Visual e a Avaliação do Ofuscamento. In: ENCONTRO NACIONAL, 13.; ENCONTRO LATINO-AMERICANO DE CONFORTO NO AMBIENTE CONSTRUÍDO, 9., Campinas, 2015. Anais... Campinas, 2015.

VEITCH, J. A. Psychological Processes Influencing Lighting Quality. Journal of the Illuminating Engineering Society, v. 30, n. 1, p. 124-140, 2001.

WARD, G. J. The RADIANCE Lighting Simulation and Rendering System. In: Annual Conference on Computer Graphics and Interactive Techniques, 21., New York, 1994. Proceedings... New York: ACM, 1994. 
WIENOLD, J.; CHRISTOFFERSEN, J.

Evaluation Methods and Development of a New

Glare Prediction Model for Daylight Environments

With the Use of CCD Cameras. Energy and

Buildings, v. 38, n. 7, p. 743-757, 2006.

\section{Acknowledgment}

The authors thank the scholarship programs PIBIC CNPq/UNESP and IAESTE, which made possible the participation in this project of Aline Yurika Inskava and Sven Thomas Planitzer, respectively.

João Roberto Gomes de Faria

Departamento de Arquitetura Urbanismo e Paisagismo, Faculdade de Arquitetura Artes e Comunicação | Universidade Estadual Paulista Júlio de Mesquita Filho | Av. Eng. Luiz Edmundo Carrijo Coube, 14-01, Vargem Limpa | Bauru - SP - Brasil | CEP 17033-360 |

Tel.: (14) 3103-6059 Ramal 7240 | E-mail: joaofari@faac.unesp.br

\section{Aline Yurila Inskava}

Graduanda em Arquitetura e Urbanismo, Faculdade de Arquitetura Artes e Comunicação | Universidade Estadual Paulista Júlio de Mesquita Filho | Rua Tamandaré, 4-18 | Bauru - SP - Brasil | CEP 17054-265 | Tel.: (14) 3236-1331 |

E-mail: ishikawa_yurika@yahoo.com.br

Sven Thomas Planitzer

Graduando em Engenharia Mecânica | University of Applied Sciences Zwickau | Siedlereck 14, 08359 | Breitenbrunn - Germany | Tel.: +(49) 173996-4913 | E-mail: sven.planitzer@fh-zwickau.de

Revista Ambiente Construído

Associação Nacional de Tecnologia do Ambiente Construído

Av. Osvaldo Aranha, $99-3^{\circ}$ andar, Centro

Porto Alegre - RS - Brasil

CEP 90035-190

Telefone: +55 (51) 3308-4084

Fax: +55 (51) 3308-4054

www.seer.ufrgs.br/ambienteconstruido

E-mail: ambienteconstruido@ufrgs.br 